\title{
High school students' attitudes toward mathematics and its relation to mathematics learning achievement
}

\author{
Khairiani Idris ${ }^{1,}$ a, $*$, Khazila ${ }^{1, b}$, Agustina ${ }^{1, c}$, Lisa ${ }^{1, d}$ \\ ${ }^{1}$ Mathematics Education Department, State Institute for Islamic Studies of Lhokseumawe \\ J1. Banda Aceh-Medan KM. 275 No. 1, Lhokseumawe, 24351, Aceh Province, Indonesia \\ E-mail: ${ }^{\mathrm{a}}$ khairiani@iainlhokseumawe.ac.id, ${ }^{\mathrm{b}}$ khazilaidris@gmail.com, ${ }^{\mathrm{c}}$ agustinahusen@ gmail.com, \\ disa_pim@yahoo.com \\ * Corresponding Author
}

\section{ARTICLE INFO}

\section{Article history}

Received: 28 December 2020

Revised: 25 May 2021

Accepted: 3 June 2021

\section{Keywords}

Correlational analysis, attitudes toward mathematics, mathematics learning achievement, mathematics learning

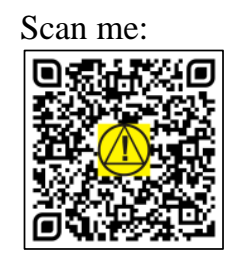

\section{ABSTRACT}

Attitudes toward mathematics have been acknowledged among factors related to students' mathematics learning achievement. The positive attitudes may decrease when the education level getting higher. This study applied a mixedmethod approach to describe students' attitudes toward mathematics and to analyze the correlation between attitudes toward mathematics and mathematics learning achievement among students in the coastal area of Aceh Province, specifically in Lhokseumawe City and North Aceh Regency. Total of 481 eleventh graders completed attitudes toward mathematics questionnaire online and 19 of them were involved in semi-structured interview. Data of mathematics learning achievement was obtained from students' scores in their report card of the previous semester. Data analyses were conducted by using Spearman's correlation and chi-square test. The results of the study revealed that attitudes toward mathematics have a weak negative correlation but significant with mathematics learning achievement. This shows that there is a small percentage of students who have low learning achievement in mathematics tend to have a positive attitude towards mathematics in the high category, while students with high achievement on the contrary. Based on the results of the study, we provide several suggestions regarding learning mathematics and the direction of further research.

How to Cite: Idris, K., Khazila, K., Agustina, A., \& Lisa, L. (2021). High school students' attitudes toward mathematics and its relation to mathematics learning achievement. Jurnal Riset Pendidikan Matematika, 8(1), 3345. https://doi.org/10.21831/jrpm.v8i1.37002

\section{INTRODUCTION}

Students' attitudes towards a particular subject are usually formed over a long period as a result of their experiences during the learning activities in that subject. Attitude is a predisposition or tendency to respond positively or negatively, like or dislike, to something in the form of an object, concept, or person (Anastasia \& Urbina, 1997; Sarmah \& Puri, 2014). Attitudes are more stable than emotions and feelings but affect student participation in class.

In mathematics, students' attitudes toward mathematics have been identified as one of the factors that play a role in improving mathematics learning achievement (Cerbito, 2020; Mazana et al., 2019; Purnomo, 2017; Trisnowali, 2017). In addition, attitudes toward mathematics also have an important role in other affective constructs in learning mathematics, including independent learning (Purnomo, 2017), self-regulation (Kusaeri \& Cahyan, 2016), and metacognitive skills (Orman \& Sevgi, 2019). On the other hand, student attitudes can also be influenced by the learning materials, learning practices, and the learning quality (Ayob \& Yasin, 2017), so that the positive attitude towards mathematics sometimes decreases when the learning content being studied is increasing or the teacher's learning method is not suitable (Mazana et al., 2019). 
Meanwhile, the mathematics achievement of students in Indonesia in international assessments is still low, as reported in the Program for International Student Assessment (PISA) (Fenanlampir et al., 2019; OECD, 2019; Schleicher, 2019) and Trends in International Mathematics and Science Study (TIMSS) (Mullis et al., 2020; Hadi \& Novaliyosi, 2019). However, the attitude of Indonesian students towards mathematics is quite positive (Kartianom \& Retnawati, 2018; Mullis et al., 2016), only 10\% of students stated "do not like learning mathematics" and $8 \%$ stated "do not value mathematics" (Mullis et al., 2012). This phenomenon has become an interesting discussion among educators, and various assumptions have been put forward. Although the international assessment was carried out for elementary and junior high school students, this phenomenon may still occur among senior high school students because attitudes are more stable and are formed from students' previous learning experiences. (Isharyadi \& Deswita, 2017).

Indonesia is an archipelago with thousands of islands that cannot be accessed easily so that education is still not evenly distributed (Fenanlampir et al., 2019). This geographical condition can be a source of the emergence of various factors that result in the low mathematics learning achievement of Indonesian students and the large difference in student achievement in areas close to the capital compared to areas far away from the capital. Several factors related to the low level of student achievement in the regions that far away from the capital are the uneven level of teacher education (Setiawan, 2019), the geographical condition of the school (Ismah \& Wibiastuti, 2015), including the difficulty of access to schools in some areas, and the limited learning facilities (Rahmahyanti et al., 2019). More specifically, schools located on the coast generally have limited educational facilities, such as the internet, which has an impact on classroom learning (Yolanda et al., 2019), especially during the current COVID-19 pandemic. This condition is also experienced by students in the province of Aceh, which is located at the westernmost and northernmost of Indonesia. Development in education has not been evenly distributed in all regencies and cities in this province (Majid, 2014).

Considering the phenomena described previously, this study was conducted to examine attitudes toward mathematics and its correlation with mathematics learning achievement in students in coastal areas of Aceh Province. More precisely, the location of the study is in Lhokseumawe City and North Aceh Regency, two areas in the northern part of the province located on the coast of the Strait of Malacca and about $300 \mathrm{~km}$ from Banda Aceh, the provincial capital. Given the above condition and character of students, the results of this study may provide a different view from previous studies focusing on the correlation between attitudes and learning achievement in mathematics. In addition, research on attitudes toward mathematics so far generally uses a quantitative approach in the form of correlational design (e.g., Jemudin et al., 2019; Kurniati \& Fakhruddin, 2018) or experimental design (e.g., Abdurahim, 2016; Astuti \& Abadi, 2015). In this study, we combine quantitative and qualitative approaches which are expected to describe students' attitudes toward mathematics more deeply and comprehensively. This description of students' attitudes toward mathematics will later be able to become a guide for teachers and schools in designing appropriate mathematics learning to increase students' positive attitudes, considering the significant impact that attitudes towards mathematics may have on students' success or failure in learning mathematics (Lipnevich et al., 2016). The results of this study will also be used as a reference for taking more appropriate policies, especially for learning mathematics in areas far away from the nation's capital, as an effort to develop education more evenly in all regions in Indonesia.

\section{METHODS}

This is a mixed-method study that combines a quantitative approach and a qualitative approach, with each approach adding something to the understanding of the phenomenon under study (Ary et al., 2010). The quantitative approach applied consists of descriptive quantitative to describe students' attitudes toward mathematics and correlational analysis which is intended to analyze the relationship between students' attitudes toward mathematics and mathematics learning achievement. The qualitative approach applied in this research is descriptive qualitative to describe students' attitudes toward mathematics in more depth. Participants, data collection, and data analysis are described in more detail as follows. 


\section{Participants}

The population in this study was all eleventh graders of Sekolah Menengah Atas (SMA) (or Senior High School), Sekolah Menengah Kejuruan (SMK) (or Vocational High School), and Madrasah Aliyah (MA) (or Islamic Senior High School) in Lhokseumawe City and the coastal part of North Aceh Regency. The total number of SMA/SMK/MA in the two regions is 59 schools, 34 of which are located in the Lhokseumawe City area and the other 25 are located in the coastal area of North Aceh Regency.

To ensure that the selected sample can be more representative of the three types of schools and the two regions of the study, we applied the proportional stratified random sampling method. This sampling method was conducted by first randomly selecting school samples in each region based on the proportion of each type of school in the region. The number of participants in each school was then determined based on the proportion of eleventh graders in each selected school.

Of the 34 schools in Lhokseumawe City, three SMAs, three SMKs, and two MAs were selected. Meanwhile, from 25 schools in North Aceh Regency, three SMAs, one SMK, and three MAs were selected. Subsequently, eleventh-grade classes were selected randomly from each school, which resulted in 493 students, 257 of them were from schools in Lhokseumawe City while the other 236 were from schools in North Aceh Regency. Of the 493 selected students, only 481 were involved as research participants, since 12 students did not respond to the research questionnaire due to several factors, e.g., not having smartphones, unstable internet network at their homes. Table 1 shows the study participants by type of school in the two research locations.

Table 1. Number of schools and participants by school type and region

\begin{tabular}{llrrrr}
\hline \multirow{2}{*}{ Region } & \multirow{2}{*}{ School/Student } & \multicolumn{3}{c}{ Type of school } & \multirow{2}{*}{ Total } \\
\cline { 2 - 5 } & & SMA & MA & SMK & \\
\hline Lhokseumawe City & Number of schools & 3 & 2 & 3 & 8 \\
& Number of students & 101 & 80 & 71 & 252 \\
\hline \multirow{2}{*}{ North Aceh Regency } & Number of schools & 3 & 3 & 1 & 7 \\
& Number of students & 170 & 36 & 23 & 229 \\
\hline Total & Number of schools & 6 & 5 & 4 & 15 \\
& Number of students & 271 & 116 & 94 & 481 \\
\hline
\end{tabular}

\section{Data collection}

Quantitative data on attitudes towards mathematics was obtained through attitudes toward mathematics questionnaire, while data on mathematics learning achievement was obtained from students' scores in mathematics subject in the previous semester contained in their report cards. Meanwhile, qualitative data on students' attitudes toward mathematics and mathematics learning achievement were obtained through interviews.

The attitudes toward mathematics questionnaire was adapted from the short version of the Attitudes Toward Mathematics Inventory (ATMI) (Majeed et al., 2013) which measures students' selfconfidence, value, enjoyment, and motivation in learning mathematics. The total statements included in this questionnaire are 32 statements, of which 7 statements are negative (see Table 2).

Table 2. Indicators of statements in the attitudes toward mathematics questionnaire

\begin{tabular}{lccr}
\hline \multirow{2}{*}{ Indicator } & \multicolumn{2}{c}{ Number of statements } & \multirow{2}{*}{ Total } \\
\cline { 2 - 3 } & Positive statement & Negative statement & \\
\hline Self-confidence & 7 & 5 & 12 \\
Value & 7 & 0 & 7 \\
Enjoyment & 8 & 1 & 9 \\
Motivation & 3 & 1 & 4 \\
Total & 25 & 7 & 32 \\
\hline
\end{tabular}

The self-confidence indicator includes statements such as the hope of getting good grades in mathematics, feeling able to learn mathematics easily, and feeling capable of problem-solving. Meanwhile, negative statements in this indicator such as learning mathematics cause feelings of nervousness, confusion, fear, dislike, and feelings of discomfort. The value indicator consists of statements that value 
the usefulness of mathematics, such as mathematics as a useful and necessary domain to learn, having a desire to develop skills in mathematics, and appreciating the value of mathematics in everyday life and outside the school environment. The enjoyment of mathematics indicator consists of statements that describe the feeling of enjoying learning mathematics, the challenge of solving new problems, the level of comfort when involved in discussions about mathematics, and feelings of happiness in learning mathematics. Lastly, the motivation indicator includes the desire to study mathematics beyond the material or content that they have to learn.

At the time this research was conducted, all of the targeted schools were implementing online learning as a result of the spread of the COVID-19 outbreak. Therefore, this questionnaire of attitudes toward mathematics questionnaire was distributed to students online in the form of Google Forms with the help of mathematics teachers.

In addition to using questionnaire and report card, information about attitudes toward mathematics was also obtained through an interview as qualitative data. A total of 19 students who have responded to the attitudes toward mathematics questionnaire from different schools were interviewed by online communication via the WhatsApp application, the most common used application during their online learning process. One or two students from each school were voluntarily involved in interviews based on their attitudes towards mathematics scores. Of the 19 students who took part in this interview, eight students (six females and two males) were from Lhokseumawe City and 11 students (seven females and four males) were from North Aceh Regency. We had previously agreed with the students about the timing of the interviews to ensure that the upcoming interviews would not interfere with their activities. The interviews were conducted through text message and/or voice message which took 50-80 minutes for each interview session.

The interview technique used is a semi-structured interview (Adams, 2015) where several main questions and several follow-up questions are prepared before conducting the interview. The interview questions were structured in such a way that they correspond to the indicators on the attitudes toward mathematics questionnaire. For example, to assess self-confidence in learning mathematics, the main question asked of students is "Do you think you would be able to master mathematics material or content if you want to study?". Follow-up questions were asked depending on the responses given by students to the main question and so on. Eight mathematics teachers were also interviewed in this study to obtain further information on the relationship between students' attitudes towards mathematics and mathematics learning achievement. The information obtained from this interview was expected to be able to support and enrich the discussion of the results of quantitative data analysis. All interview sessions were recorded and then transcribed to facilitate the qualitative data analysis process.

\section{Data analysis}

In accordance with the aims of this study, the collected data were analyzed by correlation analysis. Since one of the variables of this study, namely the mathematics learning achievement variable, was not normally distributed, the rank Spearman correlation was applied instead of the Pearson product-moment correlation, which is generally used for quantitative data. The significance of the correlation coefficient was then tested using a hypothesis test at a significance level of 5\% (0.05). In addition, as a follow-up analysis, the relationship between the two variables of the study was also analyzed using the chi-square test analysis. To perform this analysis, the data from the two variables were first grouped into three categories (low, medium, high) presented in a contingency table. The results of this chi-square analysis will show whether there is a relationship between the attitudes toward mathematics variable category and the mathematics learning achievement variable. All quantitative data analysis was carried out using IBM SPSS Statistics 25.

The results of the interviews were analyzed using three phases of content analysis techniques (Elo et al., 2014), namely the preparation, organizing, and reporting phases. The preparation of the analysis phase was carried out by reading and understanding the interview transcripts of each student in the four indicators of attitudes toward mathematics. To facilitate analysis, each student's interview transcript was given an initial or a code consisting of two letters indicating the region of the school and followed by a number that represents the order in which students were interviewed in that region. For example, SA1 represents students from North Aceh Regency who were interviewed for the first time (first-order) in that regency and SL1 represents students from Lhokseumawe City who were interviewed for the first time (first-order) in that city. Afterward, the organizing phase was performed by determining keywords 
for each indicator and categorizing these keywords based on the similarity of attitude characteristics. These two phases were carried out by three authors by discussing them together. The reporting phase was carried out by displaying the attitude category and selecting one of the written responses as a quote that is considered to be able to represent the category. The results of this report were then discussed again with all the authors.

\section{RESULTS AND DISCUSSION}

\section{Description of Attitudes Toward Mathematics and Mathematics Learning Achievement}

Table 3 displays descriptive statistics on the variables of attitudes towards mathematics and students' mathematics learning achievement. The attitude variable data has been converted in percentage form so that the comparison with the achievement variable can be described more easily.

Table 3. Description of attitudes toward mathematics and mathematics learning achievement

\begin{tabular}{lcccccc}
\hline Variable & $N$ & Range & Minimum & Maximum & $M$ & $S D$ \\
\hline Attitude & 481 & 69.63 & 24.12 & 93.75 & 59.68 & 16.26 \\
Achievement & 481 & 29.00 & 70.00 & 99.00 & 85.69 & 5.20 \\
\hline
\end{tabular}

Table 3 shows that the attitudes toward mathematics scores have a larger range and standard deviation than the achievement scores. Students' achievement data, which is a score in mathematics subject in a report card, range from 70 to 99 . The minimum score is the lowest cut-off score or standard-setting among the schools involved in this study.

Furthermore, students' attitudes toward mathematics and mathematics learning achievement were categorized into three categories, namely high, medium, and low. This categorization was carried out based on the range of possible scores for each variable, namely 20-100 for the attitude variable and 70100 for the achievement variable. The results revealed that the majority of students were in the medium category for the attitude variable and achievement variable (see Figure 1).

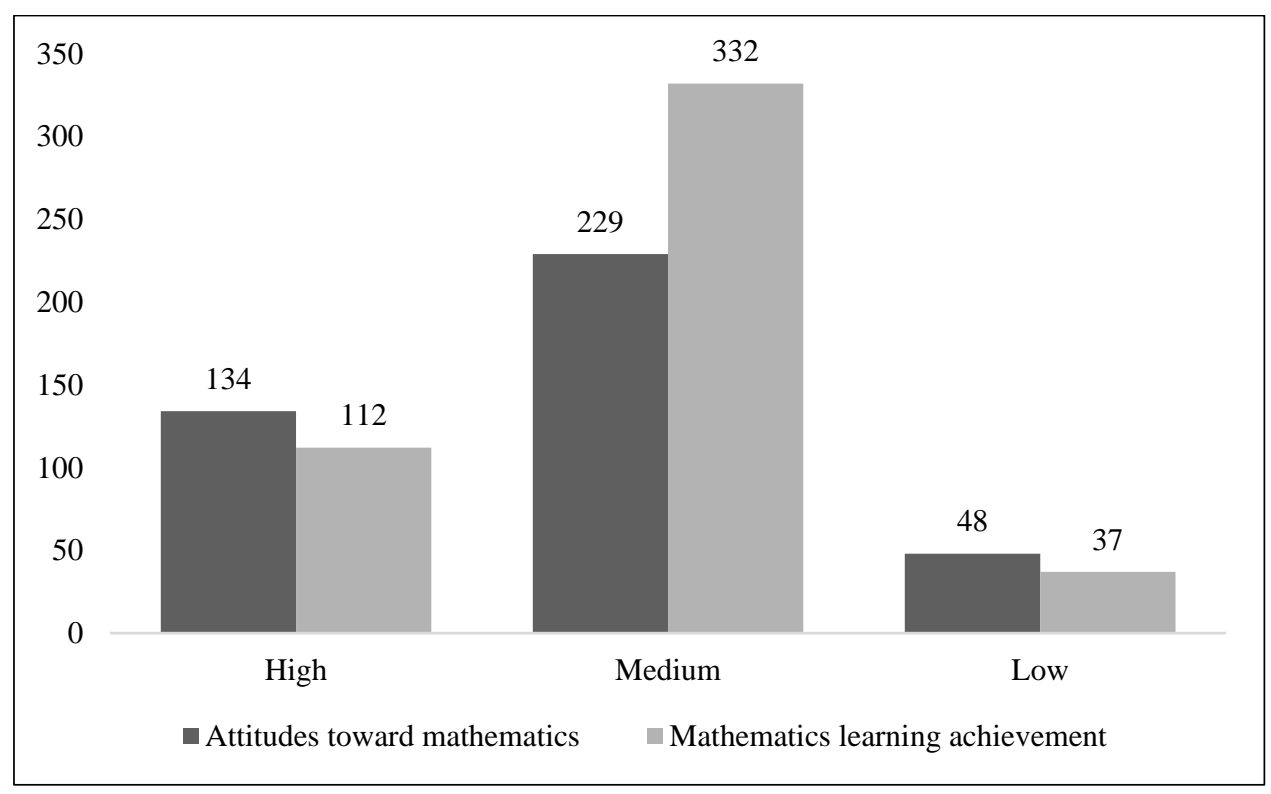

Figure 1. Distribution of students by category of attitudes toward mathematics and mathematics learning achievement $(N=481)$

From descriptive statistics on two variables, it was found that the attitudes toward mathematics of high school students in Lhokseumawe City and North Aceh Regency were generally in the medium category, and less than $10 \%$ of the total students had attitudes in the low category. Likewise with mathematics learning achievement, where students tend to be in the moderate category and only about $8 \%$ of the total students have achievement scores below 80 .

If a comparison is made between Lhokseumawe City and North Aceh Regency students, it is found that Lhokseumawe City students tend to have a much more positive attitude than students in North 
Aceh Regency (see Figure 2a). Meanwhile, the distribution of achievement data tends to be the same between students in the two regions, although the minimum score for student achievement in Aceh Utara Regency is higher (> 75) (see Figure 2b). This is due to the cut-off score or standard-setting which was set by each school for the minimum achievement score. There are schools in Lhokseumawe City that set a score of 70 as the cut-off score for mathematics subjects.

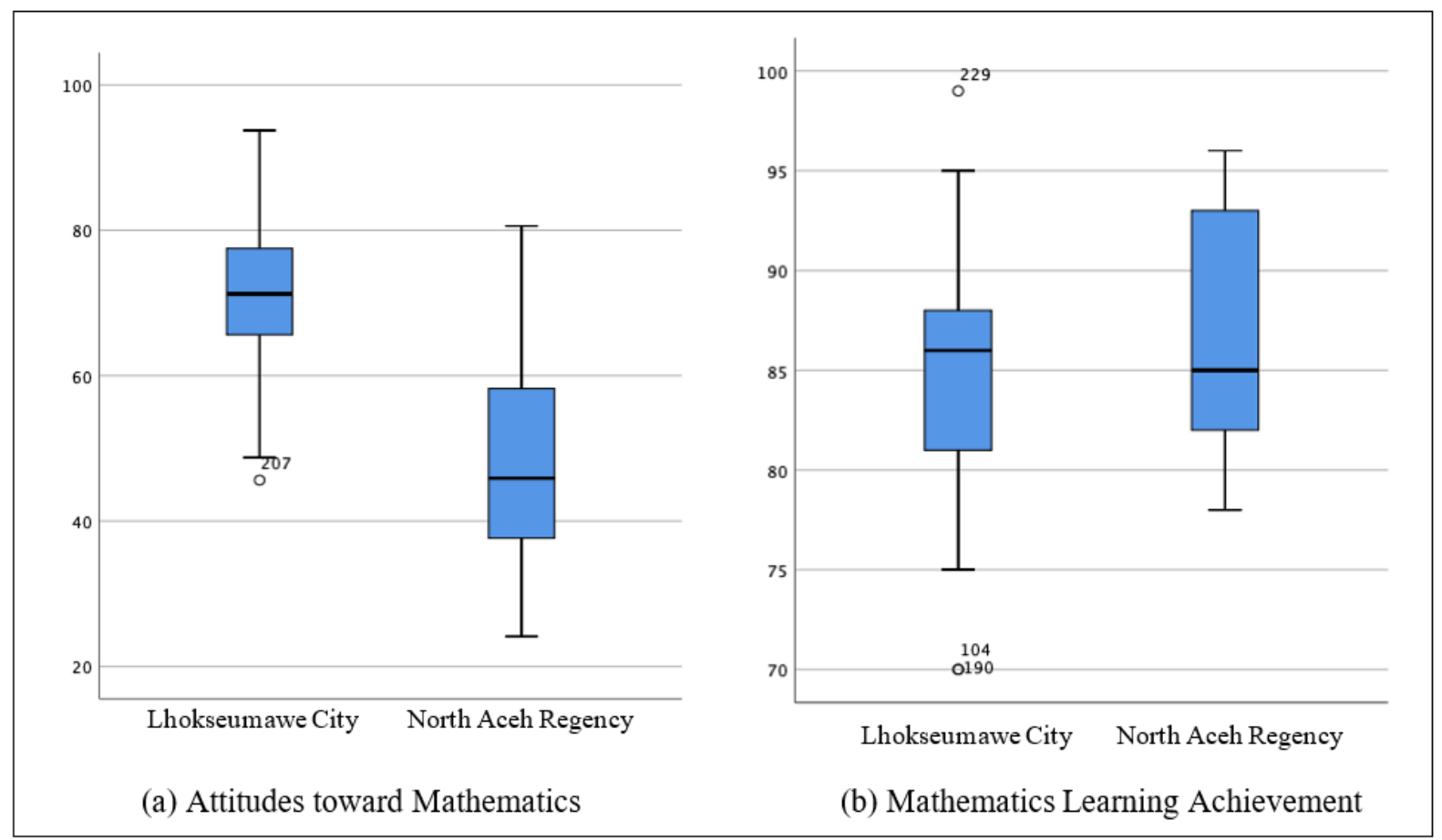

Figure 2. (a) Distribution of students' attitudes toward mathematics scores; (b) Distribution of students' mathematics learning achievement scores

\section{The Relationship between Attitudes Toward Mathematics and Mathematics Learning Achieve- ment}

The relationship between the variables of attitudes towards mathematics and mathematics learning achievement in this study was analyzed using correlation analysis. The results of the Spearman rank-order correlation analysis show that there is a weak negative correlation but significant between students' attitudes towards mathematics and mathematics learning achievement $(\rho=-0.089, p=0.05)$. Thus, it can be concluded that attitudes towards mathematics and mathematics learning achievement of high school students in Lhokseumawe City and North Aceh Regency have a very weak but significant negative correlation. This means that the increasingly positive attitudes toward mathematics is very weakly related to the decline in the learning achievement of high school students in Lhokseumawe City and North Aceh Regency.

Based on the information shown in Figure 1, the attitude and achievement categories have a high and low tendency simultaneously. This can be an indication of a correlation between attitude and achievement variables if the variables are made into categories. To analyze this further, a chi-square test was carried out to test the existence of a relationship between categories of attitude variables and achievement variables. The contingency table of the attitude and achievement category variables (see Table 4) shows that students are more likely to have positive attitudes in the medium category in each achievement category. Almost $51 \%$ of high achieving students have a medium positive attitude, the rest are more likely to have a low positive attitude $(45.5 \%)$ than those who have a high positive attitude (3.6\%). This is somewhat in contrast to students who have medium and low achievement. Among students with low achievement, $73 \%$ showed a medium positive attitude, the rest had a high positive attitude $(16.2 \%)$ which amounted to slightly more than students who had a low positive attitude $(10.8 \%)$. The chi-square test shows a significant relationship between the attitude category and the achievement 
category $\left(\chi^{2}=28.50, p=0.00\right)$ which indicates that the variation in students' learning achievement scores is related to the variation in their attitudes toward mathematics.

Table 4. Attitudes and achievement category contingency table

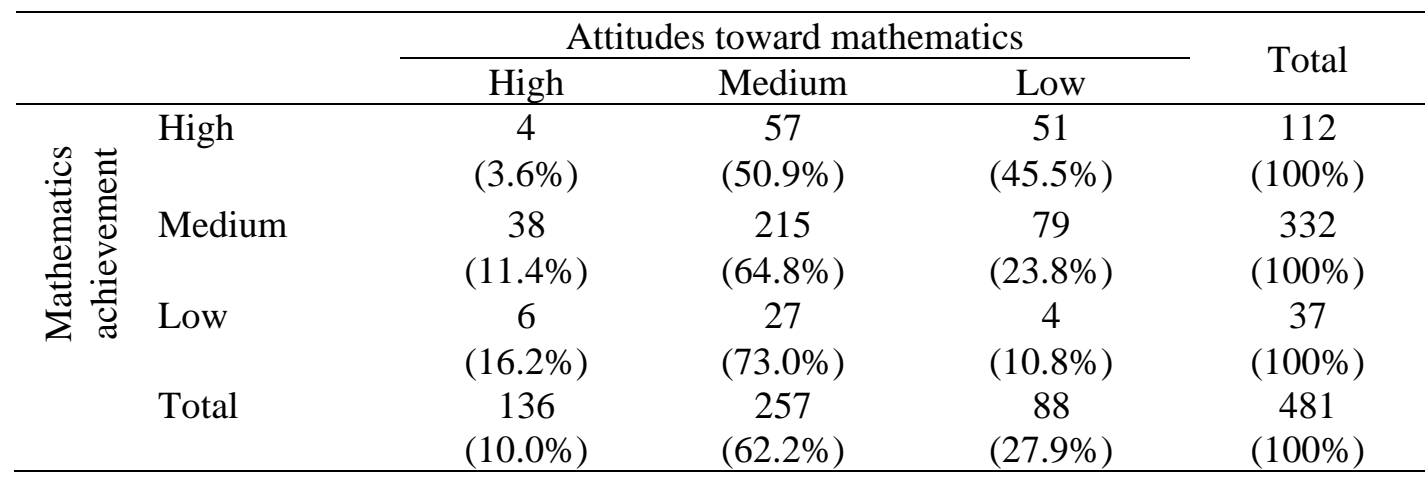

Note: The percentage displayed is the percentage for the achievement category variable

\section{Qualitative Description of Students' Attitudes Towards Mathematics}

As described in the method section, information about students' attitudes towards mathematics was studied further by conducting semi-structured interviews with 19 students who had filled out and completed a questionnaire of attitudes toward mathematics. The following describes the results of interviews conducted based on four indicators of attitudes toward mathematics; namely self-confidence, value, enjoyment, and motivation.

\section{Self-confidence}

Regarding the self-confidence in learning mathematics indicator, it was found that there was a difference in attitude between high school students in Lhokseumawe City and students in North Aceh Regency. Students in Lhokseumawe City tend to have self-confidence that they are able to understand a mathematics material if they want to learn it seriously. Meanwhile, students in North Aceh Regency stated that it was difficult to understand mathematics material, especially if they were not directly guided by the teacher in class.

“... I am capable of learning mathematics if I eager to learn with confidence [to understand] this subject." (SL4)

"If I want [to learn], I believe I can [do it]." (SL6)

However, some of the students interviewed stated that they would be able to understand the learning material depending on the level of difficulty of the material and the explanation from the teacher.

"When I learn, I usually understand what I am learning, but it also depends on the material. If the material is difficult, then I might not be able to understand it. There has to be a teacher to explain." (SL2)

In addition, there was one student interviewed who admitted that he did not like mathematics, but preferred arts and skills. However, this student stated that he believed he would be able to understand mathematics if he wanted to learn it seriously.

"I think if I want to learn, I believe I can do it. Unfortunately, to be honest, I really do not like mathematics." (SL3)

Meanwhile, high school students in North Aceh Regency who were involved in the interview generally admitted that they did not understand mathematics and needed guidance in learning.

“... because I am also not good at mathematics .... Sometimes it takes me too long to understand the mathematics problems that the teacher gives ...." (SA2)

“... I keep trying to learn until I understand .... But I also cannot understand the mathematics material that I am learning if the mathematics [material] is not explained [by the teacher], like 
now when I am learning at home, where the teacher [only] gives problems to solve, so I do not understand [the material or how to solve the problems] because it is not explained [by the teacher] ..." (SA4)

Value

The value indicator describes students' appreciation of the usefulness of mathematics. In general, students interviewed from both Lhokseumawe City and North Aceh Regency understood and appreciated the usefulness of mathematics. Among the usefulness of mathematics in everyday life that was exemplified by students are its usefulness in various jobs, as well as important numeracy skills in buying and selling transactions, dividing the inheritance, and others.

"For example, counting money and building a house. It all requires mathematics." (SL2)

"... in everyday life, we encounter many things related to mathematics, such as selling and starting a business, we need mathematics..." (SA6)

"... because with mathematics we will not be deceived by people. Especially when it comes to buying and selling." (SL8)

"Mathematics is important because mathematics can be used in any job and is also very important for the economy .... That is what I think [about the value of mathematics]." (SA2)

"[Mathematics] is essential. For example, mathematics is needed in the splitting of inheritance." (SL6)

One of the students also mentioned the relationship between mathematics and other sciences to show the value of mathematics as shown in the following interview excerpt.

"...because all of the subjects are related to mathematics, especially to science .... I think mathematics is the mother of all existing exact subjects." (SA1)

Several other students even mentioned the greater benefit of mathematics for human life, namely to shape the way of thinking.

"... learning mathematics [trains] how to think systematically brought into real life and learning mathematics [can] train the way of thinking for drawing conclusions." (SA4)

“... by learning mathematics, we are required to learn [to behave and think] more carefully and not carelessly. When we solve mathematics problems, apart from being able to solve them, we also have to be careful ... . This is what we should apply in our lives." (SL5)

“... think logically as well as creatively and can also make us more conscientious..." (SA5)

Enjoyment

The enjoyment in learning mathematics indicator describes the level of comfort and feeling of pleasure that students have in learning mathematics and participating in other activities related to mathematics. Among the students interviewed expressed their enthusiasm for learning mathematics because they like the subject.

"...because mathematics is fun." (SA8)

"Mathematics is one of my favorite subjects .... I like to spend my free time by doing the assignments in the textbook as an exercise in testing my ability and improving my calculation skills." (SA10)

“... I am really excited. It is like an adrenaline test. Anyway, I am excited to solve it [challenging mathematics problems]." (SL1)

Some students also admitted that they would be very excited if there is competition in learning, whether it is a competition in the form of games during learning, competition with classmates in an examination, or competition in mathematics outside of learning activity at school. 


\section{Jurnal Riset Pendidikan Matematika, 8 (1), 2021 - 41}

Khairiani Idris, Khazila, Agustina, Lisa

“... competition .... When the learning is made in the form of a competition, I will be more enthusiastic." (SA7)

Meanwhile, it was also found that some students admitted that they felt happy with mathematics when the material was easy to understand or the method used by the teacher was interesting. But when the material being learned is getting more complicated or the learning methods applied by the teacher are not fun, they become less enthusiastic.

"It depends on [the problem]. When I first saw the problem, I thought I could do it, [then I was] excited. But if it is hard, then ..." (SL4)

"At first [I was] excited. But if I cannot [understand or do it] anymore, then I am not excited anymore." (SL7)

"I like mathematics ... but if the teacher just explains a little and then gives notes, I do not like it." (SL2)

One student even admitted that he did not like mathematics because he thought that mathematics has too many numbers involved and formulas.

"I do not like mathematics because mathematics is closely related to counting. [Mathematics is] full of numbers and formulas. I feel bored when I have to deal with numbers or formulas like that." (SL3)

\section{Motivation}

The motivation indicator in the attitudes toward mathematics variable includes students' desire to learn mathematics in depth beyond the level they are required to learn. In this study, it was found that several students expressed their motivation in learning mathematics more diligently and deeply because of the desire to compete with friends and encouragement from family.

"... when I see my friends, who are getting better, I do not want to lose .... I also want to be great like them. So, I will try my best to be able to master mathematics even though I do not really [understand] it ..." (SA2)

However, some obstacles caused students to give up learning mathematics, including the learning methods applied and the level of difficulty of the material.

"For now, there is no fear [with mathematics], because I really like .... I used to feel scared... because when I was in junior high school, the teacher was not fun when facilitating mathematics learning in class." (SL1)

"The beginning of the learning material is fun because it is not too difficult, but if it continues, the material will be even more difficult ..." (SL8)

"It depends on the material. If the material is easy [to learn], then I will definitely feel happy and learn it diligently. However, if the material is difficult, then I will also have difficulty ..." (SL1)

\section{Discussion}

From the results of the research that has been described, it is known that the attitudes toward mathematics scores of high school students in Lhokseumawe City and North Aceh Regency has a mean of $59.68 \%$, so it can be said that it tends to be normal. Likewise, if the attitude score is categorized into three categories (low, medium, high), then it is found that more than half of the students (258 students or $53.64 \%$ ) are in the medium category.

Furthermore, from the data from interviews that have been collected, it is known that students' attitudes generally tend to vary, especially in three indicators; namely self-confidence, enjoyment, and motivation. Students' confidence in their ability to learn mathematics tends to be high for high school students in Lhokseumawe City and tends to be low for high school students in North Aceh Regency. In this case, the level of education of the parents of students might be one of the factors causing the differences that occur in the two regions, because students' self-confidence can be influenced by the level of education of their parents (Sahin et al., 2013). Statistical data on the education level of the people 
of Aceh shows that the percentage of people who have higher education is greater in Lhokseumawe City compared to North Aceh Regency (Majid, 2014).

Students' enjoyment and motivation in learning mathematics tended to vary in the two regions involved in this study. Some students stated that they enjoyed learning mathematics and some other students stated that it depends on the learning material or content and learning methods applied by the teacher. Motivation to learn mathematics is also sometimes influenced by the feeling of desiring to compete, either with friends in class or competition such as the mathematics olympiad. While in the value indicator, all students have a positive attitude, which shows that students have an understanding of the benefits of mathematics for humans and in their lives.

The results of the correlation analysis conducted in this study indicate that there are differences with several previous studies related to the correlation of attitudes and student achievement in mathematics which are generally positive (e.g., Cerbito, 2020; Mazana et al., 2019). Attitudes and student achievement in this study showed a weak negative correlation but significant. In addition, if the achievement and attitude variables were categorized into three categories (high, medium, and low), this negative relationship can still be identified. In the form of categorical variables, it is found that students who have high achievement are more likely to have medium and low positive attitudes, while students who have low achievements are more likely to have medium and high positive attitudes.

Although extremely weak, this negative correlation occurs probably due to differences in the learning material that was studied between high-achieving students and low-achieving students. A small percentage of students who have high achievements, who may come from superior schools or classes, have studied mathematics material more broadly with the higher level of difficulty of the questions discussed. From the results of the interviews, it was found that the high level of difficulty of the material was one of the triggering factors for students not liking mathematics and being less enthusiastic about learning it, in addition to the learning methods applied by the teacher. Opportunities to study mathematics material more broadly indeed cannot improve students' attitudes towards mathematics (Ayob \& Yasin, 2017), even more, if the material being taught does not focus on developing concepts, as well as critical and creative thinking skills, which often occurs in schools in Indonesia, especially schools that are far from the capital (Tanujaya et al., 2017). Meanwhile, the results regarding a small proportion of students with low achievement who tend to have high positive attitudes are in line with results from PISA (OECD, 2013) and TIMMS (Mullis et al., 2012), although involving students from different educational levels.

Thus, it is necessary to pay more attention to the content of mathematics taught in schools. For example, because more diverse assignments and applied mathematics materials have been known to make students interested in mathematics (Hamed et al., 2008), teachers need to ensure that this is conveyed in class and that no important material is not taught, such as material that emphasizes the development of mathematical concepts, as has often happened in schools (Tanujaya et al., 2017). In addition, the application of a competition and collaboration system in learning mathematics (ter Vrugte et al., 2015) could be done to increase students' learning motivation. In addition to appropriate learning practices, emotional support from teachers and proper classroom organization are also needed to improve student attitudes (Blazar \& Kraft, 2017).

The results of this study can open discourse for further research related to the correlation between students' attitudes toward mathematics and mathematics learning achievement. One of the further studies that can be done is to examine more deeply the factors that influence the attitudes toward mathematics of students who have high or low mathematics learning achievement. The results of the study will be able to provide a more comprehensive picture of students' attitudes towards mathematics, especially in regions that far away from the capital. In addition, one of the shortcomings in this study is related to the use of report cards as a source for data of mathematics learning achievement, while scores of students in the report card depend on each school's policy regarding the determination of cut-off score or standard-setting for mathematics subject. For further research, it would be better to use mathematics test scores instead of using scores from report cards, so that the scores can represent students' mathematics learning achievement more accurately. 


\section{CONCLUSION}

The results showed that high school students in Lhokseumawe City and North Aceh tend to be in the medium category of attitudes towards mathematics. In addition, it was found that there was a weak negative, but significant, correlation between students' attitudes toward mathematics and mathematics learning achievement. This may indicate that there is a small percentage of students who have high mathematics learning achievement tend to have attitudes toward mathematics in the medium or low category, while students with low achievement on the contrary. From the interviews, it was found that students' attitudes toward mathematics can be influenced by several factors, such as level of difficulty of the learning contents, learning methods applied by a teacher to facilitate learning activity, teacher and family supports, and desire to compete.

Based on the results of this study, we suggest mathematics teachers to apply learning methods or strategies that can increase students' learning interest and motivation. Among the approaches that can be applied, for example, by bringing up a system of competence or collaboration in learning mathematics, according to the character of their students. Teachers should also have the ability to support students emotionally in learning mathematics. In addition, providing examples of mathematics problems that are applicable in students' lives and emphasizing on understanding concepts may also promote students' positive attitude and achievement in mathematics. Therefore, active roles and supports from the school principals and education offices are needed, such as by providing trainings for mathematics teachers to improve their practical skills related to the pedagogical and content knowledge in mathematics

\section{REFERENCES}

Abdurahim, A. (2016). Keefektifan model pembelajaran RESIK ditinjau dari sikap, motivasi, dan kemampuan berpikir kritis matematis siswa SMP [The effectiveness of the realistic model in cooperative setting in terms of the attitude, motivation, and mathematical critical thinking skill of junior high school students]. Jurnal Riset Pendidikan Matematika, 3(2), 137-149. https://doi.org/10.21831/jrpm.v3i2.7994

Adams, W. C. (2015). Conducting semi-structured interviews. In K. E. Newcomer, H. P. Hatry, \& J. S. Wholey (Eds.), Handbook of practical program evaluation (pp. 492-505). John Wiley \& Sons. https://doi.org/10.1002/9781119171386.ch19

Anastasia, A., \& Urbina, S. (1997). Psychological testing. Prentice Hall.

Ary, D., Jacobs, L. C., Sorensen, C., \& Razavieh, A. (2010). Introduction to research in education (8th ed.). Wadsworth.

Astuti, R. D., \& Abadi, A. M. (2015). Keefektifan pembelajaran Jigsaw dan TAI ditinjau dari kemampuan penalaran dan sikap belajar matematika siswa [The effectiveness of Jigsaw and TAI learning in terms of students' reasoning competence and mathematics learning attitude]. Jurnal Riset Pendidikan Matematika, 2(2), 235-250. https://doi.org/10.21831/jrpm.v2i2.7339

Ayob, A., \& Yasin, R. M. (2017). Factors affecting attitudes towards mathematics. International Journal of Academic Research in Business and Social Sciences, 7(11), 1100-1109. http://dx.doi.org/10.6007/IJARBSS/v7-i11/3548

Blazar, D., \& Kraft, M. A. (2017). Teacher and teaching effects on students' attitudes and behaviors. Educational Evaluation and Policy Analysis, 39(1), 146-170. https://doi.org/10.3102/0162373716670260

Cerbito, A. F. (2020). Comparative analysis of mathematics proficiency and attitudes toward mathematics of senior high school student. International Journal of Scientific and Research Publication, 10(5), 211-222. http://dx.doi.org/10.29322/IJSRP.10.05.2020.p10125

Elo, S., Kääriäinen, M., Kanste, O., Pölkki, T., Utriainen, K., \& Kyngäs, H. (2014). Qualitative content analysis: A focus on trustworthiness. SAGE Open, 4(1), 1-10. https://doi.org/10.1177/2158244014522633

Fenanlampir, A., Batlolona, J. R., \& Imelda, I. (2019). The struggle of Indonesian students in the context of TIMSS and PISA has not ended. International Journal of Civil Engineering and Technology, 10(2), 393-406. 
Hadi, S., \& Novaliyosi, N. (2019). TIMSS Indonesia (Trends in international mathematics and science study). Prosiding Seminar Nasional \& Call for Papers, Program Studi Magister Pendidikan Matematika Universitas Siliwangi. http://jurnal.unsil.ac.id/index.php/sncp/article/view/1096

Hamed, S., Bahari, P., \& Abdullah, A. G. K. (2008). Korelasi antara persekitaran pembelajaran matematik, sikap pelajar terhadap matematik, dan pencapaian pelajar dalam matematik: Satu kajian kes [Correlation between mathematics learning environment, students' attitudes toward mathematics, and student achievement in mathematics: A case study]. ESTEEM Academic Journal, 4(2), 91-103. https://uppp.uitm.edu.my/component/content/article/171.html

Isharyadi, R., \& Deswita, H. (2017). Pengaruh mathematical beliefs terhadap prestasi belajar matematika siswa SMA [The effect of mathematical beliefs on senior high school students' mathematics learning achievement]. Pythagoras: Jurnal Program Studi Pendidikan Matematika, 6(1), 1-10. https://doi.org/10.33373/pythagoras.v6i1.596

Ismah, I., \& Wibiastuti, E. R. (2015). Pengaruh letak geografis sekolah terhadap konsentrasi belajar matematika siswa Sekolah Menengah Pertama [The effect of school geographical location on the concentration of mathematics learning of junior high school students]. Fibonacci: Jurnal Pendidikan Matematika dan Matematika, 1(1), 82-96. https://doi.org/10.24853/fbc.1.1.82-96

Jemudin, F. D., Makur, A. P., \& Ali, F. A. (2019). Hubungan sikap belajar dan motivasi belajar terhadap prestasi belajar matematika siswa SMPN 6 Langke Rembong [The relationship between learning attitude and motivation on mathematics learning achievement of students of SMPN 6 Langke Rembong]. Journal of Honai Math, 2(1), 1-12. https://doi.org/10.30862/jhm.v2i1.53

Kartianom, K., \& Retnawati, H. (2018). Why are their mathematical learning achievements different? Re-analysis TIMSS 2015 data in Indonesia, Japan and Turkey. International Journal on New Trends in Education and Their Implications, 9(2), 33-46. http://www.ijonte.org/FileUpload/ks63207/File/03a.k._kartianom.pdf

Kurniati, L., \& Fakhruddin, A. U. (2018). Prestasi belajar matematika ditinjau dari sikap optimis dan pesimis siswa SMA [Mathematics learning achievement based on the optimistic and pessimistic attitudes of senior high school students]. De Fermat: Jurnal Pendidikan Matematika, 1(2), 1924. https://doi.org/10.36277/defermat.v1i2.22

Kusaeri, K., \& Cahyan, E. D. H. (2016). Sikap, harapan, dan persepsi siswa pada matematika serta implikasinya terhadap kemampuan regulasi diri [Attitudes, expectations, and perceptions of students on mathematics and its implications for self-regulation skills]. Jurnal Pengajaran MIPA, 21(2), 114-121.

Lipnevich, A. A., Preckel, F., \& Krumm, S. (2016). Mathematics attitudes and their unique contribution to achievement: Going over and above cognitive ability and personality. Learning and Individual Differences, 47, 70-79. https://doi.org/10.1016/j.lindif.2015.12.027

Majeed, A. A., Darmawan, I. G. N., \& Lynch, P. (2013). A confirmatory factor analysis of attitudes toward mathematics inventory (ATMI). The Mathematics Educator, 15(1), 121-135. http://math.nie.edu.sg/ame/matheduc/tme/tmeV15_1/7.pdf

Majid, M. S. A. (2014). Analisis tingkat pendidikan dan kemiskinan di Aceh [Analysis of the level of education and poverty in Aceh]. Jurnal Pencerahan, 8(1), 15-37. https://doi.org/10.13170/jp.8.1.2040

Mazana, Y. M., Montero, C. S., \& Olifage, C. R. (2019). Investigating students' attitude towards learning mathematics. International Electronic Journal of Mathematics Education, 14(1), 207231. http://dx.doi.org/10.29333/iejme/3997

Mullis, I. V., Martin, M. O., Foy, P., \& Arora, A. (2012). TIMSS 2011 International Results in Mathematics. Boston College, TIMMS \& PIRLS International Study Center. https://timssandpirls.bc.edu/timss2011/downloads/t11_ir_mathematics_fullbook.pdf

Mullis, I. V., Martin, M. O., Foy, P., \& Hooper, M. (2016). TIMSS 2015 international results in mathematics. TIMSS \& PIRLS International Study Center at Boston College. http://timssandpirls.bc.edu/timss2015/international-results/

Mullis, I. V. S., Martin, M. O., Foy, P., Kelly, D. L., \& Fishbein, B. (2020). TIMSS 2019 international results in mathematics and science. Boston College, TIMSS \& PIRLS International Study Center. https://timssandpirls.bc.edu/timss2019/international-results/ 
OECD. (2013). PISA 2012 results in focus: What 15-year-olds know what they can do with what they know. OECD Publishing. http://www.oecd.org/pisa/keyfindings/pisa-2012-results-overview.pdf

OECD. (2019). PISA 2018 results (Volume I): What students know and can do. OECD Publishing. https://doi.org/10.1787/5f07c754-en

Orman, F., \& Sevgi, S. (2019). An investigation, based on some variables, into the attitudes of middle school students towards mathematics and metacognitive skills. Elementary Education Online, 19(1), 183-197. http://doi.org/10.17051/ilkonline.2020.649375

Purnomo, Y. (2017). Pengaruh sikap siswa pada pelajaran matematika dan kemandirian belajar siswa terhadap prestasi belajar matematika [The effect of students' attitudes on mathematics learning and students' learning independence on mathematics learning achievement]. Jurnal Kajian Pendidikan Matematika, 2(1), 93-105. http://dx.doi.org/10.30998/jkpm.v2i1.1897

Rahmahyanti, S., Hairunnisa, H. \& Sabiruddin, S. (2019). Komunikasi komunitas 1000 guru Samarinda dalam proses belajar mengajar [Community communication of 1000 Samarinda teachers in the teaching-learning process]. eJournal Ilmu Komunikasi, 7(3), 86-97.

Sahin, E., Barut, Y., \& Ersanli, E. (2013). Parental education level positively affects self-esteem of Turkish adolescents. Journal of Education and Practice, 4(20), 87-97.

Sarmah, A., \& Puri, P. (2014). Attitude towards mathematics of the students studying in diploma engineering institute (polytechnic) of Sikkim. Journal of Research \& Method in Education, 4(6), 06-10.

Schleicher, A. (2019). PISA 2018: Insights and Interpretations. OECD Publishing. https://www.oecd.org/pisa/PISA\%202018\%20Insights\%20and\%20Interpretations\%20FINAL\% 20PDF.pdf

Setiawan, A. Y. (2019). Pendidikan guru berbasis nilai dengan mengkaji penyelenggaraan guru di negara lain dalam mewujudkan visi kurikulum Indonesia yang mencerdaskan 2030 [Value-based teacher education by studying the performance of teachers in other countries in realizing the vision of the Indonesian curriculum that enlightens 2030]. GEOAREA: Jurnal Geografi, 2(1), 2534. https://ejournal.unibba.ac.id/index.php/Geoarea/article/view/216

Tanujaya, B., Prahmana, R., \& Mumu, J. (2017). Mathematics instruction, problems, challenges, and opportunities: A case study in Manokwari Regency, Indonesia. World Transactions on Engineering and Technology Education, 15(3), 287-291.

ter Vrugte, J., de Jong, T., Vandercruysse, S., Wouters, P., van Oostendorp, H., \& Elen, J. (2015). How competition and heterogeneous collaboration interact in prevocational game-based mathematics education. Computers \& Education, 89, 42-52. https://doi.org/10.1016/j.compedu.2015.08.010

Trisnowali, A. (2017). Pengaruh motivasi berprestasi, minat belajar matematika, dan sikap belajar matematika terhadap hasil belajar matematika pada siswa SMAN 2 Watampone [The effect of achievement motivation, interest in learning mathematics, and attitude in learning mathematics on mathematics learning outcomes in students of SMAN 2 Watampone]. Jurnal Matematika dan Pembelajaran, 5(2), 259-277. https://doi.org/10.24252/mapan.v5n2a8.

Yolanda, F., Sriwahyuni, T. L., Rohima, S., \& Maharani, P. (2019). Problematika pendidikan di sekolah daerah pesisir [Problems of education in schools in coastal areas]. Prosiding Seminar Nasional Peningkatan Mutu Pendidikan, 1, 514-517. http://publikasi.fkipunsam.org/index.php/semnas2019/article/view/128 